\title{
Endocrine Immune Interactions in the Host-Parasite Relationship: Steroid Hormones as Immune Regulators in Parasite Infections
}

\author{
Aguilar-Díaz H ${ }^{1}$, Nava-Castro KE², Cerbón-Cervantes MA ${ }^{1}$, Meneses-Ruiz $\mathrm{DM}^{3}$, Ponce-Regalado MD ${ }^{4}$ and Morales-Montor $\mathrm{J}^{*}$ \\ ${ }^{1}$ Facultad de Química, Departamento de Biología, Universidad Nacional Autónoma de México, México \\ ${ }^{2}$ Departamento de Ciencias Ambientales, Centro de Ciencias de la Atmósfera, Universidad Nacional Autónoma de México, México \\ ${ }^{3}$ Departamento de Inmunología, Instituto de Investigaciones Biomédicas, Universidad Nacional Autónoma de México, México \\ ${ }^{4}$ Universidad de Guadalajara, Centro Universitario de los Altos-Departamento de clínicas, México
}

\begin{abstract}
There is a close relationship between hormones, cytokines, neuropeptides, and neurotransmitters that modulate the host immune response by several effector mechanisms, including both cellular and humoral immunity. Disruption of this communication balance results in disease or in a higher susceptibility to infections. The relationships between parasites and hosts are complex and there is substantial interaction, communication and biochemical co-evolution. The role of certain hormones in parasitic infections has been demonstrated, and there are documented direct effects of hormones on parasites. Many parasites induce the secretion of molecules that influence the physiological and immunological responses in hosts, including intermediaries and vectors. Conversely, the parasites secrete many factors that alter hormone host levels. In some cases, hormones have positive or negative effects on the parasites status. In other cases, effects are mediated indirectly via the host's immune system. In vertebrates, the parasite presence also has a major influence on the host's endocrine status and the normal suite of processes governed by hormones. These processes include host development, establishment, metamorphosis, and reproduction. Thus, understanding the mechanisms involved in immunoendocrine modulation and its effects on parasites is essential for developing new drugs, finding vaccine targets and devising new therapies for several infectious diseases.
\end{abstract}

Keywords: Sexual steroids; Hormones; Parasites; Immune system

\section{Introduction}

\section{Hormones and parasites}

Parasites comprise a group of organisms that cause a massive infectious disease problem for humans and several animals of veterinary importance. These organisms are major causes of mortality and morbidity and are detrimental to both the social and economic progress of the developing world. Sex differences in parasitic infections are a biological phenomenon of considerable significance for individual health and disease. The general rule is that females are more resistant to infectious diseases than males [1,2]. However, there are many notable exceptions to this rule and illustrate a female bias in susceptibility to infection [3]. This paradigm implies that the sexual dimorphism in response to parasites is mediated primarily by the immune system of the host, which disregards the ability of some parasites to directly respond to the distinct sex steroid hormone profiles of their female and male hosts [2,4]. Sex hormones play an influential role in the control of parasitic infection by modulating different components of both the innate and adaptive immune responses. Conversely, parasites themselves are phylogenetically diverse, target a range of different tissues, and have evolved numerous alternative strategies to evade or inhibit protective immune responses by strategies, such as antigenic variation, molecular mimicry or affecting antigen processing and presentation. Moreover, parasites exploit host systems for their benefit during establishment, growth, or reproduction [4]. Consequently, the influence of sex hormones on these infective agents can be complex. Sex hormones also exert their effects through genomic and non-genomic mechanisms by interacting with cell cytoplasmic or surface receptors and triggering signaling pathways. The main biological activity occurs by the activation of specific intracellular receptors that function as ligand-activated transcription factors and coordinates the expression of target genes [5]. Our current understanding of the relationship between hormones and parasite infection suggests that parasites can synthesize proteins, such as receptors with the ability to bind host hormones, and cause downstream transcriptional gene activation. As a result, parasites can positively or negatively affect the course of infection [6,7]. Based on the above data, this review examines how hormones effect on the immune system and their implications in parasite infections.

\section{Immune response and hormones}

The immune cells: Parasite-induced host response is orchestrated by the complex interactions of molecular and cellular effectors. The innate immune system is the first line of defense that is activated soon after parasite exposure. The cells involved in the host defense are neutrophils, macrophages, natural killer cells (NK) and dendritic cells (DCs) [8]. However, the primary response is performed by neutrophils using two basic mechanisms involving phagocytosis and the release of potent and toxic oxygen-free radicals (respiratory burst) [9] Macrophages also participate in phagocytosis and respiratory bursts. These cells have the additional ability to present antigens and secrete cytokines, growth factors, and tissue-remodeling agents to alter tissue development $[10,11]$. DCs are professional antigen presenting cells that function by antigen-presentation on the cell surface to activate $\mathrm{T}$ lymphocytes. Finally, NK cells have a cytotoxic phenotype and secrete

*Corresponding author: Jorge Morales Montor, Departamento de Inmunología, Instituto de Investigaciones Biomédicas, Universidad Nacional Autónoma de México. AP 70228, México, E-mail: Jmontor66@biomedicas.unam.mx

Received August 29, 2015; Accepted December 24, 2015; Published Decembe 28,2015

Citation: Aguilar-Díaz H, Nava-Castro KE, Cerbón-Cervantes MA, Meneses-Ruiz DM, Ponce-Regalado MD, et al. (2015) Endocrine Immune Interactions in the Host-Parasite Relationship: Steroid Hormones as Immune Regulators in Parasite Infections. J Steroids Horm Sci 6: 165. doi:10.4172/2157-7536.1000165

Copyright: ( $) 2015$ Clave S, et al. This is an open-access article distributed unde the terms of the Creative Commons Attribution License, which permits unrestricted use, distribution, and reproduction in any medium, provided the original author and source are credited. 
Citation: Aguilar-Díaz H, Nava-Castro KE, Cerbón-Cervantes MA, Meneses-Ruiz DM, Ponce-Regalado MD, et al. (2015) Endocrine Immune Interactions in the Host-Parasite Relationship: Steroid Hormones as Immune Regulators in Parasite Infections. J Steroids Horm Sci 6: 165. doi:10.4172/2157-7536.1000165

small proteins called perforins and proteases known as granzymes. These proteins are involved in the host-rejection of tumors and virally infected cells. In general terms, these responses do not require prior exposure and can be initiated immediately following exposure to a novel parasite. Interestingly, the activity and number of cells associ ated with innate immunity could differ between the sexes. In females, professional antigen presenting cells (APC) are more efficient at presenting peptides than APC from males. Additionally, the phagocytic activity of macrophages and neutrophils is higher in females than males [12-14]. After parasitic or antigenic stimulation, the production of prostaglandin, thromboxane, and nitric oxide (NO) is higher in females than males [15]. In contrast, other studies demonstrate that several pro-inflammatory cytokines (including IL- 6 and TNF- $\alpha$ ) are higher in males following trauma [15]. Women with regular menstrual cycles and women during the luteal phase exhibit lower NK cell activity than men. These results correlate with experimental work in mice that demonstrated estradiol could reduce both the number and activity of NK cells [16-18]. However, males and females differ in their innate immune responses. This finding suggests there are sex differences. Previous studies of both humans and rodents have shown that inflammatory immune responses are generally higher in females than males. Thus, these results could explain the higher female susceptibility to developing inflammatory rheumatic diseases, such as rheumatoid arthritis and systemic lupus erythematous [19].

The acquired immune response after parasitic infection is mediated by humoral and cellular activation that includes an antigen-specific mechanism. Antigen presenting cells (macrophages and DCs) have a critical role in this response and stimulate $\mathrm{B}$ cells and $\mathrm{T}$ cell subsets [20]. B cells are grouped into B1 and B2 cells and are responsible for antibody secretion [21]. $\mathrm{T}$ cells are categorized into four distinct subtypes based on transcriptional factors, cytokine production, and function. These subtypes include Th1, Th2, Th17 and regulatory T cells (Treg) [22]. In this cell-mediated immune response there is a marked difference between males and females. Thus, T-cells (particularly CD4 T-cells) can be differentiated depending of the cytokine release and are functionally and phenotypically heterogeneous. Similarly, $\mathrm{T}$ cells present different subsets (i.e., Th1 or Th2 cells) to overcome infection and differ between males and females. Females have stronger Th2 responses (i.e., higher IL-4, IL-5, IL-6, and IL-10 production) than males [23]. There are also reports that females have a higher Th1 response (i.e., higher concentrations of IFN- $\gamma$ ) than males. In rodent models, females show higher mitogen-stimulated lymphocyte proliferation, faster wound healing, and increased immunological intolerance to foreign substances than males $[15,24,25]$.

\section{Hormones}

Estrogens: Estrogens (E2) are predominantly produced in gonadal tissue and are principally produced by theca and granulosa cells in the ovary and mesenchymal cells [26]. The E2 immunomodulatory role enables the autoimmune disease incidence and age-associated diseases such as hormone-dependent cancer, osteoporosis, and cardiovascular diseases [27]. It has been observed that E2 has immunological roles and suppresses bone marrow leukocyte production, including neutrophils [28]. Estrogens also modulate leukocyte chemotaxis during ischemia and myocardium reperfusion in rat by inhibiting TNF- $\alpha$ production and limiting the binding of deleterious ICAM-1 leukocytes to injured myocardium. Therefore, estrogens protect against myocardial ischemia-reperfusion injury [29]. Previous in vitro studies have shown antioxidant effects by limiting superoxide anion production in human neutrophils [30]. E2 administration in mice before spinal cord injury reduces the production of tissue associated cytokines, such as TNF- $\alpha$, IL-6, and IL- $1 \beta$ (Table 1) [31].

During the first week of pregnancy in mice when E2 peak occurs, there is an increase of peritoneal macrophage phagocytic activity [32] Additionally, exogenous in vivo E2 replacement significantly elevates sera lipopolysaccharide-binding protein levels and the cell surface expression of Toll-like receptor 4 (TLR-4) and CD14 (Table 1) [33]

In other murine model studies, exposure to E2 in vitro promotes differentiation into functional $\mathrm{CD} 11 \mathrm{c}^{+}$and $\mathrm{CD} 11 \mathrm{~b}^{+} \mathrm{DCs}$ from bone marrow precursor cells. However, this differentiation is inhibited in E2-deficient medium and also, by estrogen receptor (ER) antagonists (ICI 182, 780 and tamoxifen). The differentiation can be restored by E2 addition in physiological amounts [34]. Moreover, E2 increases DC activation marker expression, including the expression of major histocompatibility complex II (MHCII), CD80 (B7.1), CD86 (B7.2), CD40, CD14, CXCL8 and CCL2 in murine bone marrow-derived DCs (Table 1) [35].

Conversely, the exposure of bone marrow-derived dendritic cells (BMDCs) to E2 enhances IL-12 production in response to the TLR ligands (as CpG and LPS) and induces killer DCs (IKDCs) activity and IFN- $\gamma$ production. However, there is no difference between the number and function of DCs isolated from spleens of female C57BL/6 mice ovariectomized and ovariectomized mice with E2 replacement (Table 1) [36]. The DCs and monocytes derived from rat spleens with experimental autoimmune encephalomyelitis and differentiated with IL-4 and GM-CSF produce more NO when incubated with E2 (Table 1) [37].

The results of in vitro experiments show that NK and NKT cell numbers are increased by E2 stimulation [38]. The cell increase is probably caused by the up regulation of MCM7 and MCM10, which control cell proliferation [39]. However, E2 stimulation reduced NK and NKT cytotoxicity by decreasing the expression of soluble factors, such as granzyme B and FasL. Additionally, CD69, NKp46, NKG2DL and 2B4 receptors were downregulated, which inhibited NK cell activation (Table 1) [40].

In general, E2 exerts different effects on T-lymphocytes by altering cytokine production and modulating cell proliferation. Thus, low E2 concentrations can promote the Th1 response and cell-mediated immunity. However, high concentrations augment Th2 responses and humoral immunity [41]. The splenic lymphocytes and $\mathrm{T}$ cells purified from mice treated with E2 show upregulation of the transcription factor T-bet, and this causes IFN- $\gamma$ production and Th 1 cell migration (Table 1) [42]. In several models, increased IL-4 expression from Th2 cells positively correlates with cyclical variations in estrogen levels in humans [43]. Moreover, mice treated with high doses of estrogen have decreased IL-17 production by Th17 cells [44]. Treg cell frequency increases in pregnant mice exposed to E2 through the transcriptional induction of Foxp3, IL -10, and PD-1 overexpression in both lymphoid organs and blood compared to non-estrogen treated or non- pregnant mice (Table 1) [45,46]. In other mouse models, long-term exposure to exogenous high doses of E2 enhances polyclonal B cell activation [47]. Physiological concentrations of E2 stimulate B antibody production by B lymphocytes in the genital tract and systemic lymphoid tissues of normal cycling female macaques during the menstrual cycle periovulatory period [48]. In male and female humans, E2 enhances IgG and IgM production by peripheral blood mononuclear cells (PBMCs) without altering cell viability, proliferation, or non-specific differentiation (Table 1) [49]. 
Citation: Aguilar-Díaz H, Nava-Castro KE, Cerbón-Cervantes MA, Meneses-Ruiz DM, Ponce-Regalado MD, et al. (2015) Endocrine Immune Interactions in the Host-Parasite Relationship: Steroid Hormones as Immune Regulators in Parasite Infections. J Steroids Horm Sci 6: 165. doi:10.4172/2157-7536.1000165

Page 3 of 12

\begin{tabular}{|c|c|c|c|}
\hline Hormones & Immune cells & Effect & References \\
\hline \multirow{5}{*}{ Estradiol (E2) } & Neutrophils & $\begin{array}{l}\text { Regulate the number and function } \\
\text { Decrease chemotaxis by altering the expression of ICAM-1 } \\
\text { Decrease superoxide anion production } \\
\text { Produce cytokines TNF- } \alpha, \text { IL-6, and IL-1beta }\end{array}$ & [28-31] \\
\hline & Macrophages & $\begin{array}{l}\text { Increase macrophage phagocytic activity } \\
\text { Increase CD14, LBP and TLR42 }\end{array}$ & {$[32,33]$} \\
\hline & Dendritic cells & $\begin{array}{l}\text { Promote functional differentiation } \\
\text { Increase the expression of MHC II, CD14, CD40, CD80, CD86, CXCL8 and } \\
\text { CCL2 } \\
\text { Induce IKDCs and increase nitric oxide }\end{array}$ & [34-36] \\
\hline & NK cells & $\begin{array}{l}\text { Decrease cytotoxicity } \\
\text { Upregulate the number of cells and expression of CD69, NKp46, NKG2DL, } \\
\text { CD244, granzyme B and FasL }\end{array}$ & {$[39,40]$} \\
\hline & Lymphocytes & $\begin{array}{l}\text { Upregulate T-bet expression (Th1 and proinflammatory cytokines) } \\
\text { Increase IL-4 production from CD4+ T cells } \\
\text { Decrease production of IL-17 } \\
\text { Upregulate Treg cells (expression of Foxp3, IL-10 and PD-L1) } \\
\text { Stimulate antibody production }\end{array}$ & [42-49] \\
\hline \multirow{4}{*}{$\begin{array}{l}\text { Progesterone } \\
\qquad(\mathrm{P} 4)\end{array}$} & Macrophages & Inhibition classical pathway activation (iNOS and arginase activity) & [61] \\
\hline & Dendritic cells & $\begin{array}{l}\text { Inhibit the activity of mature DCs } \\
\text { Down-regulate TNF- } \alpha \text {, IL-1 } \beta, \text { MHC II, CD80 } \\
\text { Inhibit DC-stimulated proliferation of T cells }\end{array}$ & [62] \\
\hline & NK cells & $\begin{array}{l}\text { Regulate differentiation (Hox-A10) } \\
\text { Reduce in cytotoxicity (HLA-G) Inhibit of perforin } \\
\text { release (PIBF) } \\
\text { Th2 differentiation and cytokine production (PIBF) }\end{array}$ & {$[13,14,63,66]$} \\
\hline & Lymphocytes & $\begin{array}{l}\text { Promote differentiation of Th2 } \\
\text { Induce migration of Treg cells to the pregnant uterus }\end{array}$ & {$[13,181]$} \\
\hline Testosterone & Macrophages & Inhibit the function of macrophages & [12] \\
\hline \multirow[t]{3}{*}{ (T4) } & & $\begin{array}{l}\text { Reduce TLR4 expression } \\
\text { Inhibit NO production }\end{array}$ & \\
\hline & APC's & Down-regulate IL-1 $\beta$, IL- 6 and TNF- $\alpha$ & [70] \\
\hline & Lymphocytes & $\begin{array}{l}\text { Reduce Th1 cytokine release } \\
\text { Induce Th2 profile } \\
\text { Maintain Treg cells }\end{array}$ & {$[72,73]$} \\
\hline \multirow[t]{3}{*}{ DHEA } & Neutrophil & Increase superoxide generation & [75] \\
\hline & Dendritic cells & Induce mature DCs & [76] \\
\hline & Lymphocytes & $\begin{array}{c}\text { Enhance IL-2 secretion of Th1 cells and cytotoxicity function of T cells } \\
\text { Induce apoptosis pathway Fas/Fas-L }\end{array}$ & {$[77,78]$} \\
\hline
\end{tabular}

Table 1: Effects of steroids hormones on immune response. 
Citation: Aguilar-Díaz H, Nava-Castro KE, Cerbón-Cervantes MA, Meneses-Ruiz DM, Ponce-Regalado MD, et al. (2015) Endocrine Immune Interactions in the Host-Parasite Relationship: Steroid Hormones as Immune Regulators in Parasite Infections. J Steroids Horm Sci 6: 165. doi:10.4172/2157-7536.1000165

One remarkable effect that E2 can exert (concentration-dependent) is a proinflammatory or anti-inflammatory response. Low levels of E2 induce TNF- $\alpha$, IL-6, and IL-1 $\beta$. E2 also inhibits Th2-type cytokines and increases leukocyte migration to sites of inflammation [41]. However, at high levels, E2 inhibits cell-mediated immunity and decreases the expression of activation markers [50,51]. E2 inhibits TNF- $\alpha$, IL-1 $\beta$, and IL- 6 production by T cells, macrophages, and DCs. Conversely, E2 induces Th2-type cytokines, such as IL-4, IL-10, and TGF- $\beta$, that results in anti-inflammatory effects [52]. E2 peak levels reduce Th1type cytokine production (TNF- $\alpha$ and IFN- $\gamma$ ) by T cells, macrophages, and DCs $[41,53,54]$. E2 also enhances antibody production by enhancing IL-10 in human peripheral blood mononuclear cells (Table 1) [49]. In the female genital tract, $E 2$ elevates IgG, IgA, and SC levels in ovariectomized rat uterus [55,56]. However, E2 action on cervicovaginal IgA, IgG, and SC is independent of the uterine influence because the E2 treatment of rats with ligated uterocervical junctions had decreased cervicovaginal IgA and SC levels. This is an important finding if the uterus is the main antibody source in genital tract secretions. After hysterectomy, the levels of $\operatorname{IgG}$ are reduced by one half and the levels of IgA are decreased by 15-fold [56]. E2 also affects lymphocytes, macrophages, NK cells and the migration and infiltration of other cells into the female genital tract. Additionally, E2 inhibits MCP-1 expression in endometrial stromal cells by controlling endometrial macrophage migration [57]. Furthermore, high E2 levels decrease macrophage and inflammatory $\mathrm{T}$ cell recruitment through ICAM-1, E-selectin, and VCAM-1 downregulation [58]. In contrast, E2 increases $\mathrm{CD}_{56}{ }^{+} \mathrm{NK}$ cell recruitment to human endometrium by CXCL10 and CXCL11 chemokine upregulation [59]. Finally, E2mediates the inhibition of antigen presentation and CTL activity in the female reproductive tract through the induction of TGF- $\beta$ production by the uterine epithelial cells (Table 1) [60].

Progesterone: The hormone progesterone (P4) is secreted by the corpus luteum in the ovary and placenta. Principally, P4 is involved in the regulation of the female menstrual cycle and in pregnancy and embryogenesis of humans and other species. During early pregnancy, P4 recruits macrophages into the endometrium. The macrophages contribute to embryo implantation and pregnancy initiation by altering the remodeling process, uterine decidual response and placental trophoblast invasion. In mice, $\mathrm{P} 4$ negatively regulates macrophage activation of innate and classical pathways associated with $\mathrm{NO}$ and IL-12 production by down regulating inducible nitric oxide synthase 2 (iNOS) and arginase (Table 1) [61].

DCs derived from LPS-activated rat bone marrow cells treated with P4 have suppressed pro-inflammatory cytokine secretion (TNF- $\alpha$, IL$1 \beta)$. Additionally, the expression of activation markers, such as MHC class II and CD80, are downregulated. This causes reduced stimulation and T lymphocyte proliferation (Table 1) [62]. Moreover, P4 suppresses several innate immune responses including macrophage and NK cell activity and NF- $\kappa B$ signal transduction [63]. Activated lymphocytes express $\mathrm{P} 4$ receptors during pregnancy and high levels can stimulate the synthesis of progesterone-induced binding factor (PIBF) [14]. $\mathrm{P} 4$ also increases Th2 type cytokine production by IL-4 receptor stimulation and subsequent activation of the Jak/STAT pathway (Table 1) [13]. This activation results in inflammatory Th 1 responses both at the maternal fetal interface and systemically $[64,65]$.

Previous studies have demonstrated that P4 exerts a strong immunosuppressive effect on the production and transepithelial transport of IgG and IgA [56]. Studies of ovariectomized rats treated with P4 showed a significant decline in IgA and IgG cervicovaginal expression. In monocytes, $\mathrm{P} 4$ inhibits $\mathrm{NK}$ cell activity and $\mathrm{F} c \gamma \mathrm{R}$ expression and reduces antibody-dependent cell cytotoxicity mediated by the progesterone-induced blocking factor (PIBF) [66]. Finally, membrane-associated and intracellular progesterone receptors are expressed by a number of immune cells including macrophages, $\mathrm{NK}$ cells, and $\gamma \delta$-T cells $[62,67]$.

Testosterone: Testosterone (T4) is the main androgen secreted by testicular Leydig cells in males. It is also produced in small quantities by ovarian theca cells in females in response to the luteinizing hormone [68]. T4 inhibits histamine and serotonin release by mast cells after stimulation by compound $48 / 80$ or neuropeptide P [69]. In vitro studies with macrophage (RAW 264.7 cells) cell lines treated with T4 showed decreased TLR-4 expression and TLR-4 specific ligand sensitivity. Furthermore, orchidectomized mice are more susceptible to lethal LPS challenge in vivo. Interestingly, significantly higher TLR4 cell surface expression was observed in macrophages isolated from these animals (Table 1) [12]. Moreover, treating a group of diabetic men with T4 decreased IL- $1 \beta$, IL-6, and TNF- $\alpha$ production ex vivo by APCs (Table 1) [70]. Further evidence of the role for T4 in regulating immunity is obtained from studies of male medical castration, which decreases Treg cell levels. In contrast, androgen therapy replenishes the Treg cell numbers (Table 1) [71].

Female $S J L$ mice are more susceptible than males to experimental autoimmune encephalomyelitis (EAE) induced by myelin basic protein (MBP) specific T lymphocytes. However, the females implanted with dihydrotestosterone exhibited a significantly less severe EAE course (Table 1) [72]. Finally, T4 inhibits immunoglobulin IgM and IgG production. A recent study using human peripheral blood mononuclear cells (PBMC) demonstrated this effect is mediated indirectly by $\mathrm{T} 4$ inhibition of monocyte-derived IL-6 production (Table 1) [73].

Dehydroepiandrosterone: Dehydroepiandrosterone (DHEA) is a pregnenolone-derived C-19 steroid that is predominantly synthesized in the adrenal cortex cells [74]. DHEA sulfate ester (DHEAS) activates recombinant protein kinase C-beta (PKC-beta), which results in amplified phosphorylation of p47 (phox). Phosphorylated p47 is an active component of the reduced nicotinamide adenine dinucleotide phosphate complex responsible for neutrophil superoxide generation (Table 1) [75]. Additionally, DHEAS synergizes with GM-CSF and IL-4 to generate mature DCs from monocytes (Table 1) [76]. Moreover, DHEAS regulates cytokine production by both myeloid and lymphoid cells. Thus, most reports suggest this steroid is a potent inducer of IL-2 secretion by Th1 cells and human T cell cytotoxic function (Table 1) [77]. Finally, DHEA enhances Fas and Fas-L expression to induce thymocyte apoptosis [78].

\section{Hormones, immune response and parasitic infection}

In helminths infections: Protective immunity against helminth parasites is generally dependent on the development of a strong Th2 response involving IL-4 and IL-13. In general, females are more resistant than males. This is particularly true for gut parasitic helminth infections. There are many examples (Strongyloides ratti) where gonadectomy significantly reduces worm burdens in male rats but ovariectomy has no effect on parasite burdens in females [79]. Thus, increased male susceptibility to gut parasitic nematodes may be a direct result of androgenic as opposed to estrogenic influences on immunity. As a result, ovariectomy of females has no effect, but injection of testosterone into females or males increases gut worm burdens [79]. Nippostrongylus brasiliensis infection of Indian soft-furred rats reveals that males are more susceptible to infection since parasite burdens are higher in males 
Citation: Aguilar-Díaz H, Nava-Castro KE, Cerbón-Cervantes MA, Meneses-Ruiz DM, Ponce-Regalado MD, et al. (2015) Endocrine Immune Interactions in the Host-Parasite Relationship: Steroid Hormones as Immune Regulators in Parasite Infections. J Steroids Horm Sci 6: 165. doi:10.4172/2157-7536.1000165

than in females after 4 weeks of infection [80]. According to this, orchidectomy reduced parasite burdens in males while ovariectomy had no effect in females [80]. The intestinal parasite Trichuris muris is a significant example illustrating how sex hormones influence mast cell activity in female mice by favoring gut parasitic nematode expulsion [81]. Studies utilizing cytokine deficient mice might reveal underlying mechanisms modulating sex hormone influences on immunity and outcomes of parasite infection. Female C57BL/6, BALB/c IL-4 $-/$ and $\mathrm{BALB} / \mathrm{c}$ mice showed T. muris infection resistance; however, male C57BL/6, IL-4 ${ }^{-/-}$and BALB/c are susceptible. This observation reflects the female ability to generate IL-13 $[82,83]$. In experimental assays, the administration of recombinant IL-13 to male BALB/c IL-4 -/- induces worm expulsion, while IL-13 neutralization in BALB/c IL-4 -/- inhibited expulsion $[82,83]$. These results suggest there is a possible link between E2 and the ability to produce IL-13 or IL-4 as mediators of resistance against this parasite and the infection susceptibility is a consequence of inadequate $\mathrm{TH} 2$ cells production $[82,83]$.

In the case of the intracellular parasite Trichinella spiralis, estrogens can increase the resistance of male CD1 mice to parasites, as measured both by adult worm burdens and tissue larvae [84]. Gonadectomy also increases male resistance and T4 treatment increases female susceptibility. Consequently, both T4 and E2 influence T. spiralis control in a reciprocal manner, and this control is Th2 dependent [84]. Mast cells also play a crucial role in worm expulsion as in the case of $T$. muris [85]. These results suggest that sex hormones influence the Th2 response during gut parasitic infections and demonstrate the invariable female resistance to helminthic parasites (including filarial nematodes, in which Th2 responses promote resistance to infection). Litomosoides sigmodontis filarial survival is reduced in males compared to female $\mathrm{BALB} / \mathrm{c}$ mice and the microfilariae prevalence and density are higher in females [86]. The susceptibility of BALB/C mice to L. sigmodontis is caused by the generation of potent regulatory $\mathrm{T}$ cell responses that overcome Th2 effector functions and permit survival of the adult parasite [87]. It is important to emphasize that E2 at physiological levels expands $\mathrm{CD} 4{ }^{+} \mathrm{CD} 25^{+} \mathrm{FoxP} 3^{+}$regulatory $\mathrm{T}$ cells expressing IL$10[87,88]$ and that IL-10 is essential for microfilariae persistence [89].

Several groups have demonstrated that in vitro culture of Taenia solium cysticerci in the presence of sex steroid (P4) induces evagination in $100 \%$ of treated cysticerci [90]. In contrast, T4 and DHEA induce the opposite effect and inhibits $85 \%$ to $90 \%$ of evagination events [5]. The use of the P4 competitive antagonist RU486 inhibits the evagination process in cysticerci, and this effect is mediated by a classical steroid receptor that is able to block the transcription of some genes [90]. The use of flutamide (androgen antagonist) does not reverse the T4 and the DHEA effect [5]. These results suggest the cysticerci evagination process could be mediated by a specific P4-receptor present on the parasite (Figure 1) [90]. In contrast, host treatment with $\mathrm{P} 4$ reduces the number of parasitic worms [91]. The effect of E2 on T. crassiceps cysticerci showed that the hormone is able to induce budding and increase the parasite infective capacity to $200 \%$ [5]. The effect could be mediated through a specific estrogen receptor that promotes the expression of $c$-fos and $c$-jun (AP-1 transcriptional complex) and suggests that E2 has proliferative effects on the parasite [92]. Our laboratory also demonstrates that exposure of T. crassiceps cysticerci to E2 and $\mathrm{P} 4$ induced differential protein expression patterns regarding to changes in actin, tubulin and myosin expression altering flame cells at the level of the ciliary tuft [93]. In contrast T4 and DHT induced $90 \%$ of mortality caused by an alteration in the function of flame cells, without changes in actin, tubulin or myosin expression [94].
DHEA has been shown to affect different stages of Schistosoma mansoni in vitro. The treatment with DHEA decreases adult worm oviposition and increases the cercariae mortality rate to $100 \%$ [95]. In mouse models of $S$. mansoni infection, the sex difference is reversed and the female mice are more susceptible to infection because they develop higher inflammatory responses as measured by organ weights and delayed type hypersensitivity responses [96]. In mice, adrenalectomy exacerbates disease, as measured by worm burden and host mortality following inoculation with S. mansoni parasites [97]. In contrast, human males are more susceptible to $S$. mansoni infection than females [98]. In the case of Schistosoma hematobium, the treatment with $\mathrm{T} 4$ decreases the adult parasite reproductive capacity and reduces its fecundity through sexual hormone interaction with a glutathione S-tranferase (Sh28GST) to inhibit parasite metabolism [99]. A stimulant effect of murine epidermal growth factor (EGF) has been found on Brugia malayi microfilariae in vitro. EGF induces overexpression of Raf and Ran transcriptional levels and causes microfilariae growth and differentiation [100]. These experimental reports suggest that some human helminth and nematode parasites have molecular structures analogous to the classic hormone receptors. These receptors have similar functions as in mammals (Figure 1) $[4,5,101]$.

In protozoa infections: In parasitic protozoa, some hormonal effects have also been reported on different morphologic stages. In Toxoplasma gondii murine infection models, females develop severe brain inflammation and are more likely to die following infection than males [102]. Male mice produce higher concentrations of TNF- $\alpha$, IL12 , and IFN- $\gamma$ than females during acute infection [102,103]. In female mice, ovariectomy reduces and administration of E2 exacerbates tissue cyst development caused by T. gondii infection [104,105]. The ovariectomized female mice treated with pharmacological doses of potent E2 compounds including $17 \beta$-estradiol, diethylstilbestrol, or alpha-dienestrol, renders mice more susceptible to disease as measured by brain cyst formation [105]. The host treatment with T4 reduces the parasite number and pathology [104,106]. T. gondii infection in rodents results in pronounced behavioral alterations including increased exploratory behavior and aggression. These changes may make the infected animal more conspicuous to and reduces definitive host fear (the cat) $[107,108]$. However, different studies with genetically engineered mice have shown that $T$. gondii stimulates the innate immune response during the initial parasite establishment and growth. During chronic infection, the disease state can be maintained directly by adaptive immune responses to control and benefit both host and parasite survival [109]. To achieve this outcome, T. gondii express a number of TLR ligands, including GPI-anchors [110], HSP70 [111,112] and profilin [113]. The parasite also induces IL-12 production through CCR5 receptor ligation [114]. These processes result in the activation of macrophages, DCs, and NK cells that produce IL-12, TNF- $\alpha$, and IFN- $\gamma$. The production of cytokines can control parasite growth, induce Th1 cell expansion and facilitate the cytotoxic $\mathrm{CD}^{+} \mathrm{T}$ cell development $[115,116]$. Plasmodium sp. infection is similar between males and females [117], however, previous studies suggested that males have higher parasitic burdens $[118,119]$, but females have higher mortality rates [120]. It has been observed that cortisol treatment in vitro in $P$. falciparum merozoites increases the size and number of gametocytes produced. E2 treatment increases parasite growth and reproduction [121,122]. In contrast, prolactin can mediate lethal effects on various parasite stages [123]. In diseased rodent models using Plasmodium chabaudi female C57BL/10 [119,120] and C57BL/6 [124] mice, there was less 
Citation: Aguilar-Díaz H, Nava-Castro KE, Cerbón-Cervantes MA, Meneses-Ruiz DM, Ponce-Regalado MD, et al. (2015) Endocrine Immune Interactions in the Host-Parasite Relationship: Steroid Hormones as Immune Regulators in Parasite Infections. J Steroids Horm Sci 6: 165. doi:10.4172/2157-7536.1000165

Page 6 of 12

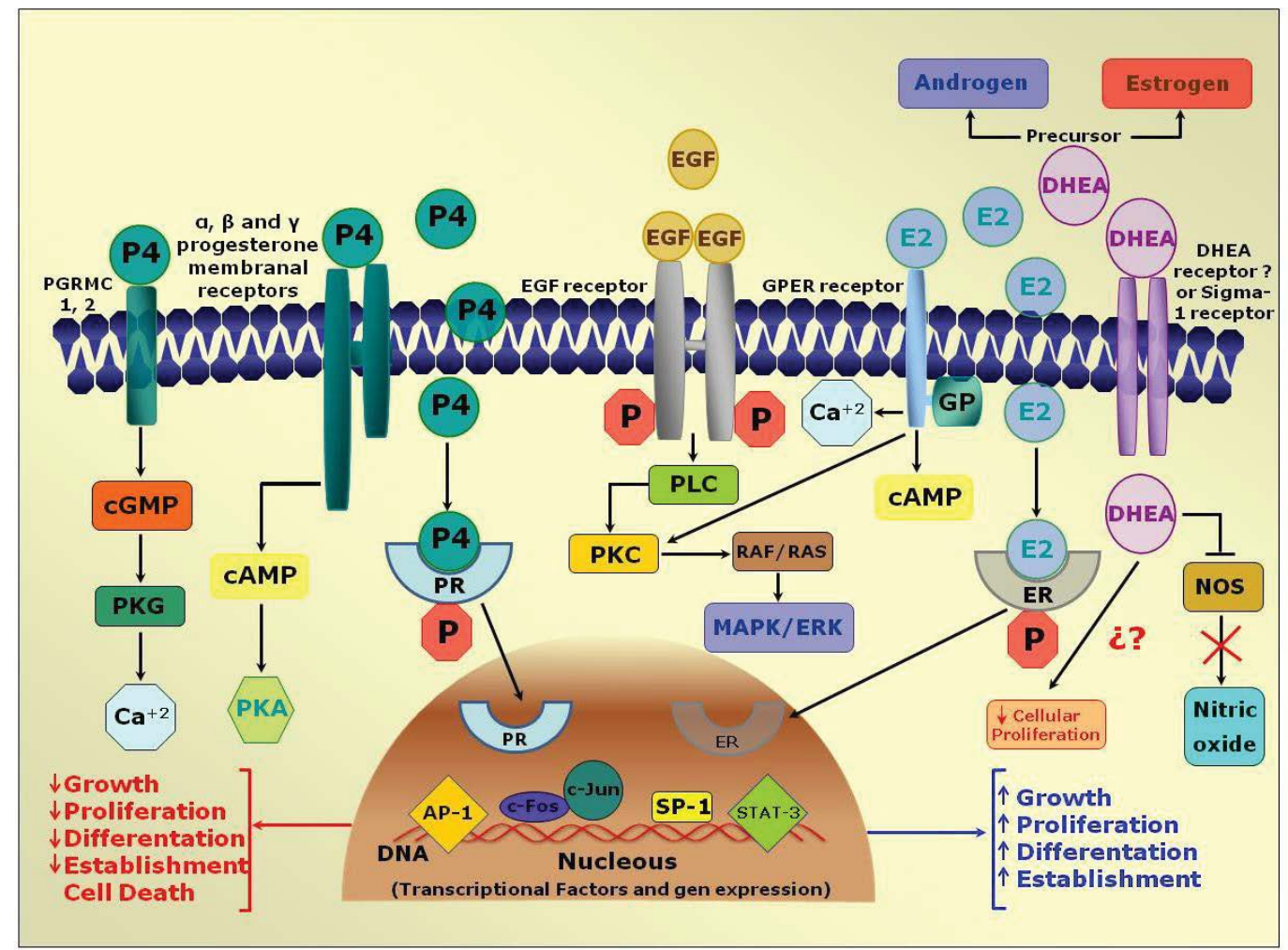

Figure 1. Signaling pathways and positive or negative effects of different hormones on the growth, differentiation, proliferation and establishment of parasitic cells. Some hormone signals are involved in the expression of transcription factors in the cell nucleus (genomic effects). These factors regulate the gene expression or the second messenger expression (no genomic effects), which results in the activation and/or inhibition of signaling cascades. DHEA: dehydroepiandrosterone; P4: Progesterone; EGF: murine epidermal growth factor; E2: 17- $\beta$-Estradiol.

parasitic induced mortality compared with male mice. Moreover, during P. chabaudi infection, T4 is a key modulator in the sexual dimorphism exhibited. Hormonal treatment in females can prevent self-healing, whereas male castration leads to self-healing $[125,126]$. Interestingly, in this disease model T4 is not signaling through classical androgen or estrogen receptor [125-128]. In vivo assays showed that female C57BL/10 mice orally administered $\mathrm{T} 4$ had increased mortality rates and death was associated with a decreased peritoneal cell generation of reactive oxygen species [129].However, in P. falciparum T4 and DHEA increase the growth and parasite reproduction [123]. Finally, $\mathrm{T} 4$ treatment of females results in $\mathrm{CD}^{+} \mathrm{T}$ cell increases in the spleen and decreases in numbers of overall splenocytes [130]. Conversely, P4 treatment in mice increases growth and reproduction and favored parasite establishment [122]. Recent data showed that gonadectomy of increased $\mathrm{T}$ and $\mathrm{B}$ splenic cells in both sexes, increased macrophages cells and decreased the NK subpopulation only in male mice infected with Plasmodium berghei ANKA. Gonadectomy also induced an increase in the synthesis of IgG1, IgG2b, IgG3, and total IgG; the proinflammatory cytokines TNF- $\alpha$ and IL- 6 and induced higher levesl of NO only in female mice. This suggest that female sex hormones have anti- inflammatory properties in malaria $[131,132]$.

The intestinal protozoans Entamoeba sp. and Giardia sp. are transmitted fecal-orally and cause amoebiasis and giardiasis, respectively. During infection neutrophils play an important role in both diseases. For example, the alpha-defensins secreted by neutrophils in vitro have anti-giardial properties [133] and neutrophil- depleted mice have more severe amoebic liver abscess (ALA) and intestinal amoebiasis [134]. Macrophages produced NO is involved in protection of invasive amoebiasis [135]. Additionally, mast cells play a critical role in controlling giardiasis [136]. Studies performed using C57BL/6 mice infected with Giardia muris showed that male mice have higher parasite burdens in their gut $[137,138]$, and more prolonged disaccharidase deficiency [138] than females. Moreover, infected female C57BL/6 mice had elevated levels of parasite-specific IgG and stronger IgG2b and IgG3 responses than males [139]. In $E$. histolytica human infection the invasive disease predominates in males compared to females [140]. Studies in mice have demonstrate that females show a significantly early IFN- $\gamma$ production and the presence of Natural Killer T-cells (NKT) cells compared with male mice, which have higher levels of IL-4-producing cells. This cytokine and NKT cells seem to be important in the control of the disease since the use of IFN-gamma-neutralizing monoclonal antibodies or NKT-deficient female mice showed an exacerbated amoebic liver absses (ALA) [141]. In vitro exposure to DHEA and cortisol increase E. histolytica trophozoite proliferation and DNA synthesis. DHEA also induces a progressive loss of adherence capacity, which is crucial during intestinal infection [134] (Figure 1). In contrast, during intestinal infection treatment with testosterone ( $\mathrm{T} 4)$ stimulated trophozoites migration from intestine to liver and increased ALA infections [141].

Trypanosoma spp. is the causal agent to Chagas' disease in America and sleeping sickness in Africa. Chagas' disease consists of acute and chronic phases. Although the role of the immune system during 
Citation: Aguilar-Díaz H, Nava-Castro KE, Cerbón-Cervantes MA, Meneses-Ruiz DM, Ponce-Regalado MD, et al. (2015) Endocrine Immune Interactions in the Host-Parasite Relationship: Steroid Hormones as Immune Regulators in Parasite Infections. J Steroids Horm Sci 6: 165. doi:10.4172/2157-7536.1000165

Page 7 of 12

disease clearance and pathogenesis is not well understood, studies have shown sex hormones play a role in disease modulation. It is well documented that male mice and rats are more susceptible to disease than females in T. cruzi experimental infection [142-145]. In addition, males are clinically more likely to develop severe cardiomyopathies [146] and exhibit abnormal electrocardiograms more often than females [147]. Data indicates that EGF induces an increase in the growth, metabolic activity, and DNA synthesis of Trypanosoma cruzi trypomastigotes in vitro. Additionally, EGF induces the expression of receptors with tyrosine kinase activity, protein kinase C (PKC), and mitogen-activated protein kinases (MAPK) [148]. Susceptibility and/or resistance could be directly linked to the presence of female sex hormones, and ovariectomized females are more susceptible to disease $[142,145,148]$. However, a role for male sex hormones in mediating susceptibility is less clear, and gonadectomized males are reported to have reduced parasite burdens [145] and unaltered parasitemia and mortality [142]. Interestingly, female mice treated with high pharmacological doses of $17 \beta$-estradiol increases parasitemia and mortality. The low physiological doses have either no effect or reduced parasite burden and death [143]. DHEA administration after T. cruzi infection plays an essential role in enhancing host resistance. The macrophages infected with T. cruzi express different hormonal receptors and secrete more TNF- $\alpha$, IL-12 and NO after treatment with DHEA. This cytokine secretion results in a decreased trypomastigote load in blood and suggests its protective role is a result of potent immunoregulatory actions during infection $[149,150]$.

In the sleeping sickness caused by T. brucei spp., the disease is characterized by two distinct stages; an early hemolytic stage followed by a late meningoencephalitic stage. This last phase is characterized by leukocyte infiltration into the central nervous system, astrocyte and microglial activation, and acute neuroinflammation that ultimately results in coma and death [151]. African trypanosomes have developed many mechanisms to evade host immune response. However, most important is their ability to switch immunodominant variant surface glycoprotein (VSG's), exchange the antigen surface and always avoid the immune response [152,153]. In this case, sex hormones play a role in modulating immunity to African trypanosomes. Researchers have found that female mice have lower parasitemia and survive longer than their male counterparts [154]. During human disease, males have trypanosomes in their cerebral spinal fluid more often than females and males have more relapses following treatment [155]. Unfortunately, no further research has determined the roles of specific sex hormones during disease. It has been shown that infection can result in hypogonadism and decreased T4 and E2 levels in both clinical and experimental studies [156-159].

Human babesiosis is caused by the intraerythrocytic protozoan parasite called Babesia microti. Researchers studying this infection have found that male mice are more susceptible to disease [160]. However, studies of WA1-type babesial report that female mice are more susceptible [160]. While the mechanisms behind female susceptibility to WA1-type babesial are unclear, research into male susceptibility to B. microti indicates that $\mathrm{T} 4$ causes longer and more severe infections in mice that have been castrated and implanted with T4 compared to mice castrated and implanted with inert oil $[161,162]$. Additionally, higher-ranking mice within a home cage have higher T4 higher levels, and these higher levels are associated with depressed levels of serum immunoglobulin and reduced resistance to infection with B. microti [163]. Interestingly, ixodidae ticks preferentially attach to rodents with high T4 levels [162]. Although T4 exacerbates disease, E2 does not confer resistance to $B$. microti disease [164]. More research is required to examine both the basic immune responses against Babesia parasites and the role that sex hormones play during disease. Additional studies investigating differences between parasite species and mouse strains are also needed.

The sexually transmitted parasite Trichomonas vaginalis is an extracellular mucosal protozoan with a progressive growth. Several studies show that $T$. vaginalis has androgen and estrogen receptors on its cell surface (Figure 1) [165]. Interestingly, to study T. vaginalis in the laboratory, female mice must receive estrogen treatments to establish disease [166,167]. Similarly, in clinical studies, female volunteers also require estrogen treatment to establish the disease [168]. Furthermore, conditions associated with high levels of estrogen, such as menses and pregnancy, can exacerbate T. vaginalis infections [169]. 17 $\beta$-estradiol enhances the in vitro growth of parasites, whereas T4 and P4 inhibit growth at early phases. Other studies using euthymic and athymic BALB/c mice found that females are more susceptible than males at developing abscesses following subcutaneous injections of T. vaginalis [170]. Conversely, some in vitro studies have found that E2 inhibits T. vaginalis growth [171] and both virulence factor and cell-detaching factor, which are correlated with disease severity [172].

Leishmania spp. is an obligate intracellular protozoan parasite transmitted by the bite of certain sandfly species. In humans infected with $L$. mexicana, females generally have increased Thl responses, as measured by DTH reactions and decreased Th2 responses and IgE production compared to males [173]. In L. major infections, gonadectomy increases male resistance and T4 implants increase female susceptibility [174]. Similarly, E2 promotes macrophage mediated killing of $L$. mexicana at physiological levels through increased NO production independent of proinflammatory cytokine expression [175]. During L. donovani infection, T4 regulates murine bone marrow-derived macrophage p38 MAPK activation in a negative manner, and this promotes parasite survival [176]. L. mexicana infection is more severe than L. major infection because virulence is based on downregulation of macrophage function and IFN $-\gamma$ induced Jak1, Jak2, and STAT1 activation $[177,178]$. E2 upregulates IFN- $\gamma$ mRNA expression by T cells [39] whereas T4 inhibits production of this cytokine [71]. The IL-10 cellular sources are potentially subject to sex hormone control [179]. Thus, the Th1/Th2 paradigm of resistance/susceptibility to intracellular parasites is a gross oversimplification of a far more complicated network of regulatory/counter-regulatory interactions that are also subject to further modulation by sex hormones.

\section{Conclusion}

As previously mentioned, during many parasitic infections, there is a reciprocal relationship amongst sex steroids, the immune system, and the eventual elimination or establishment of the parasites in humans. In certain cases, hormones can regulate the innate immune response and the subsequent adaptive immune response [180].

The hormonal microenvironment may favor or inhibit the survival of parasites differentially between the sexes. This result may represent a highly evolved host-parasite relationship in which certain hormones appear to serve as proliferation or death factors that influence the establishment of infection and are independent of the host immune response. All of to the data suggest the parasites exploit endocrine mechanisms developed by the host for its own advantage.

The elucidation of neuroimmunoendocrine interactions during parasite infections is fundamental to understand the mechanisms involved in parasite establishment, growth, and reproduction in human 
Citation: Aguilar-Díaz H, Nava-Castro KE, Cerbón-Cervantes MA, Meneses-Ruiz DM, Ponce-Regalado MD, et al. (2015) Endocrine Immune Interactions in the Host-Parasite Relationship: Steroid Hormones as Immune Regulators in Parasite Infections. J Steroids Horm Sci 6: 165. doi:10.4172/2157-7536.1000165

Page 8 of 12

hosts. A deeper comprehension of this complex relationship could have implications in the control and treatment of various infections throughout the world. The physiologic elements that are essential in the network of neuroimmunoendocrine interactions during parasite infection could have a deep biological and physiopathological impact. Thus, a better understanding could be extremely valuable in designing vaccines and new antiparasitic drugs and in controlling various human and veterinary parasitosis. It may also lead to the development of new therapies for autoimmune diseases.

\section{Acknowledgements}

Financial support: Grant \#176803 was obtained from Programa de Fondos Sectoriales CB-SEP, Consejo Nacional de Ciencia y Tecnología (CONACyT) and Grant IN208715 was obtained from Programa de Apoyo a Proyectos de Innovacion Tecnologica, Direccion General de Asuntos del Personal Academico, Universidad Nacional Autonoma de Mexico, both provided to Jorge Morales-Montor. Hugo Aguilar-Díaz had a posdoctoral fellowship from Programa de Becas Posdoctorales Dirección General de Asuntos de Personal Académico (DGAPA) UNAM, and Dulce María Meneses Ruiz was a recipient of a posdoctoral fellowship from CB2010/151747 CONACYT, UNAM

\section{References}

1. Nacher $M$, Singhasivanon $P$, Treeprasertsuk $S$, Silamchamroon $U$ Phumratanaprapin W, et al. (2003) Gender differences in the prevalences of human infection with intestinal helminths on the Thai-Burmese border. Ann Trop Med Parasitol 97: 433-435.

2. Nava-Castro K, Hernández-Bello R, Muñiz-Hernández S, Camacho-Arroyo I, Morales-Montor J (2012) Sex steroids, immune system, and parasitic infections: facts and hypotheses. Ann N Y Acad Sci 1262: 16-26.

3. Poulin R (1996) Helminth growth in vertebrate hosts: does host sex matter? Int J Parasitol 26: 1311-1315.

4. Escobedo G, Roberts CW, Carrero JC, Morales-Montor J (2005) Parasite regulation by host hormones: an old mechanism of host exploitation? Trends Parasitol 21: 588-593.

5. Escobedo G, Larralde C, Chavarria A, Cerbón MA, Morales-Montor J (2004) Molecular mechanisms involved in the differential effects of sex steroids on the reproduction and infectivity of Taenia crassiceps. J Parasitol 90: 1235-1244.

6. Ibarra-Coronado EG, Escobedo G, Nava-Castro K, Jesus Ramses CR Hernandez-Bello R, et al. (2011) A helminth cestode parasite express an estrogen-binding protein resembling a classic nuclear estrogen receptor Steroids 76: 1149-1159.

7. Taubert S, Ward JD, Yamamoto KR (2011) Nuclear hormone receptors in nematodes: evolution and function. Mol Cell Endocrinol 334: 49-55.

8. Magor BG, Magor KE (2001) Evolution of effectors and receptors of innate immunity. Dev Comp Immunol 25: 651-682.

9. Faurschou M, Borregaard N (2003) Neutrophil granules and secretory vesicles in inflammation. Microbes Infect 5: 1317-1327.

10. Sindrilaru A, Scharffetter-Kochanek K (2013) Disclosure of the Culprits: Macrophages-Versatile Regulators of Wound Healing. Adv Wound Care (New Rochelle) 2: 357-368

11. Sunderkötter C, Steinbrink K, Goebeler M, Bhardwaj R, Sorg C (1994) Macrophages and angiogenesis. J Leukoc Biol 55: 410-422.

12. Rettew JA, Huet-Hudson YM, Marriott I (2008) Testosterone reduces macrophage expression in the mouse of toll-like receptor 4 , a trigger for inflammation and innate immunity. Biol Reprod 78: 432-437.

13. Szekeres-Bartho J, Faust Z, Varga P, Szereday L, and Kelemen K (1996) The immunological pregnancy protective effect of progesterone is manifested via controlling cytokine production. American journal of reproductive immunology $35,348-351$.

14. Szekeres-Bartho J, Polgar B (2010) PIBF: the double edged sword. Pregnancy and tumor. Am J Reprod Immunol 64: 77-86.

15. Klein SL (2004) Hormonal and immunological mechanisms mediating sex differences in parasite infection. Parasite Immunol 26: 247-264.

16. Miller L, Hunt JS (1996) Sex steroid hormones and macrophage function. Life
Sci 59: 1-14.

17. Roberts CW, Walker W, Alexander J (2001) Sex-associated hormones and immunity to protozoan parasites. Clin Microbiol Rev 14: 476-488.

18. Robinson DP, Klein SL (2012) Pregnancy and pregnancy-associated hormones alter immune responses and disease pathogenesis. Horm Behav 62: 263-271.

19. Pennell LM, Galligan CL, Fish EN (2012) Sex affects immunity. J Autoimmun 38: J282-291.

20. Schlitzer A, McGovern N, Ginhoux F (2015) Dendritic cells and monocytederived cells: Two complementary and integrated functional systems. Semin Cell Dev Biol 41: 9-22.

21. Allman D, Pillai S (2008) Peripheral B cell subsets. Curr Opin Immunol 20 149-157.

22. Raphael I, Nalawade S, Eagar TN, Forsthuber TG (2015) T cell subsets and their signature cytokines in autoimmune and inflammatory diseases. Cytokine 74: 5-17.

23. Girón-González JA, Moral FJ, Elvira J, García-Gil D, Guerrero F, et al. (2000) Consistent production of a higher TH1:TH2 cytokine ratio by stimulated T cells in men compared with women. Eur J Endocrinol 143: 31-36.

24. Blankenhorn EP, Troutman S, Clark LD, Zhang XM, Chen P, et al. (2003) Sexually dimorphic genes regulate healing and regeneration in MRL mice. Mamm Genome 14: 250-260.

25. Krzych U, Strausser HR, Bressler JP, and Goldstein AL (1981) Effects of sex hormones on some $T$ and $B$ cell functions as evidenced by differential immune expression between male and female mice and cyclic pattern of immune responsiveness during the estrous cycle. Prog Clin Biol Res 70: 145-150.

26. Simpson ER (2003) Sources of estrogen and their importance. J Steroid Biochem Mol Biol 86: 225-230.

27. Ansar Ahmed S, Penhale WJ, Talal N (1985) Sex hormones, immune responses, and autoimmune diseases. Mechanisms of sex hormone action. Am J Pathol 121: 531-551.

28. Gaunt SD, Pierce KR (1985) Myelopoiesis and marrow adherent cells in estradiol-treated mice. Vet Pathol 22: 403-408.

29. Squadrito F, Altavilla D, Squadrito G, Campo GM, Arlotta M, et al. (1997) 17 Beta-oestradiol reduces cardiac leukocyte accumulation in myocardia ischaemia reperfusion injury in rat. Eur J Pharmacol 335: 185-192.

30. Bekesi G, Tulassay Z, Racz K, Feher J, Szekacs B, et al. (2007) The effect of estrogens on superoxide anion generation by human neutrophil granulocytes: possible consequences of the antioxidant defense. Gynecological endocrinology : the official journal of the International Society of Gynecological Endocrinology 23: 451-454.

31. Cuzzocrea S, Genovese T, Mazzon E, Esposito E, Di Paola R, et al. (2008) Effect of 17 beta-estradiol on signal transduction pathways and secondary damage in experimental spinal cord trauma. Shock 29: 362-371.

32. Baranao RI, Tenenbaum A, Sales ME, and Rumi LS (1992) Functiona alterations of murine peritoneal macrophages during pregnancy. American journal of reproductive immunology 27: 82-86.

33. Rettew JA, Huet YM, Marriott I (2009) Estrogens augment cell surface TLR4 expression on murine macrophages and regulate sepsis susceptibility in vivo. Endocrinology 150: 3877-3884.

34. Paharkova-Vatchkova V, Maldonado R, and Kovats S (2004) Estrogen preferentially promotes the differentiation of CD11c+ CD11b(intermediate) dendritic cells from bone marrow precursors. Journal of immunology 172: 14261436.

35. Bengtsson AK, Ryan EJ, Giordano D, Magaletti DM, Clark EA (2004) 17betaestradiol (E2) modulates cytokine and chemokine expression in human monocyte-derived dendritic cells. Blood 104: 1404-1410.

36. Siracusa MC, Overstreet MG, Housseau F, Scott AL, Klein SL (2008) 17betaestradiol alters the activity of conventional and IFN-producing killer dendritic cells. J Immunol 180: 1423-1431.

37. Zhang QH, Hu YZ, Cao J, Zhong YQ, Zhao YF, et al. (2004) Estrogen influences the differentiation, maturation and function of dendritic cells in rats with experimental autoimmune encephalomyelitis. Acta Pharmacol Sin 25: 508-513.

38. Baral E, Nagy E, Berczi I (1995) Modulation of natural killer cell-mediated 
Citation: Aguilar-Díaz H, Nava-Castro KE, Cerbón-Cervantes MA, Meneses-Ruiz DM, Ponce-Regalado MD, et al. (2015) Endocrine Immune Interactions in the Host-Parasite Relationship: Steroid Hormones as Immune Regulators in Parasite Infections. J Steroids Horm Sci 6: 165. doi:10.4172/2157-7536.1000165

cytotoxicity by tamoxifen and estradiol. Cancer 75: 591-599

39. Nakaya M, Tachibana H, Yamada K (2006) Effect of estrogens on the interferongamma producing cell population of mouse splenocytes. Biosci Biotechnol Biochem 70: 47-53.

40. Hao S, Zhao J, Zhou J, Zhao S, Hu Y, et al. (2007) Modulation of 17betaestradiol on the number and cytotoxicity of NK cells in vivo related to MCM and activating receptors. Int Immunopharmacol 7: 1765-1775.

41. Straub RH (2007) The complex role of estrogens in inflammation. Endocr Rev 28: $521-574$.

42. Karpuzoglu E, Phillips RA, Gogal RM Jr, Ansar Ahmed S (2007) IFN-gammainducing transcription factor, T-bet is upregulated by estrogen in murine splenocytes: role of IL-27 but not IL-12. Mol Immunol 44: 1808-1814.

43. Faas M, Bouman A, Moesa H, Heineman MJ, de Leij L, et al. (2000) The immune response during the luteal phase of the ovarian cycle: a Th2-type response? Fertil Steril 74: 1008-1013.

44. Wang C, Dehghani B, Li Y, Kaler LJ, Vandenbark AA, et al. (2009) Oestrogen modulates experimental autoimmune encephalomyelitis and interleukin-17 production via programmed death 1. Immunology 126: 329-335.

45. Polanczyk MJ, Hopke C, Vandenbark AA, and Offner H (2007) Treg suppressive activity involves estrogen-dependent expression of programmed death-1 (PD1). International immunology 19: 337-343.

46. Tai $P$, Wang J, Jin $H$, Song $X$, Yan J, et al. (2008) Induction of regulatory T cells by physiological level estrogen. J Cell Physiol 214: 456-464.

47. Nilsson N, Carlsten H (1994) Estrogen induces suppression of natural killer cell cytotoxicity and augmentation of polyclonal B cell activation. Cell Immuno 158: 131-139.

48. Lü FX, Abel K, Ma Z, Rourke T, Lu D, et al. (2002) The strength of B cell immunity in female rhesus macaques is controlled by $C D 8+T$ cells under the influence of ovarian steroid hormones. Clin Exp Immunol 128: 10-20.

49. Kanda N, Tamaki K (1999) Estrogen enhances immunoglobulin production by human PBMCs. J Allergy Clin Immunol 103: 282-288.

50. Attanasio R, Gust DA, Wilson ME, Meeker T, and Gordon TP (2002) Immunomodulatory effects of estrogen and progesterone replacement in a nonhuman primate model. Journal of clinical immunology 22: 263-269.

51. Enomoto LM, Kloberdanz KJ, Mack DG, Elizabeth D, and Weinberg A (2007) Ex vivo effect of estrogen and progesterone compared with dexamethasone on cell-mediated immunity of HIV- infected and uninfected subjects. Journal of acquired immune deficiency syndromes 45: 137-143.

52. Zang YC, Halder JB, Hong J, Rivera VM, Zhang JZ (2002) Regulatory effects of estriol on $\mathrm{T}$ cell migration and cytokine profile: inhibition of transcription factor NF-kappa B. J Neuroimmunol 124: 106-114.

53. Härkönen PL, Väänänen HK (2006) Monocyte-macrophage system as a target for estrogen and selective estrogen receptor modulators. Ann N Y Acad Sc 1089: $218-227$

54. Salem ML, Hossain MS, and Nomoto K (2000) Mediation of the immunomodulatory effect of beta- estradiol on inflammatory responses by inhibition of recruitment and activation of inflammatory cells and their gene expression of TNF-alpha and IFN-gamma. International archives of allergy and immunology 121: 235-245.

55. Jalanti R, Isliker H (1977) Immunoglobulins in human cervico-vagina secretions. Int Arch Allergy Appl Immunol 53: 402-408.

56. Wira CR, Sandoe CP (1989) Effect of uterine immunization and oestradio on specific $\lg A$ and $\lg$ antibodies in uterine, vaginal and salivary secretions. Immunology 68: 24-30.

57. Kaushic C, Frauendorf E, Rossoll RM, Richardson JM, Wira CR (1998) Influence of the estrous cycle on the presence and distribution of immune cells in the rat reproductive tract. Am J Reprod Immunol 39: 209-216.

58. Nakagami F, Nakagami H, Osako MK, Iwabayashi M, Taniyama $\mathrm{Y}$, et al (2010) Estrogen attenuates vascular remodeling in $\mathrm{Lp}(\mathrm{a})$ transgenic mice. Atherosclerosis 211: 41-47

59. Sentman CL, Meadows SK, Wira CR, Eriksson M (2004) Recruitment of uterine NK cells: induction of CXC chemokine ligands 10 and 11 in human endometrium by estradiol and progesterone. J Immunol 173: 6760-6766.
60. Wira CR, and Rossoll RM (2003) Oestradiol regulation of antigen presentation by uterine stromal cells: role of transforming growth factor- $\beta$ production by epithelial cells in mediating antigen- presenting cell function. Immunology 109 : 398-406.

61. Menzies FM, Henriquez FL, Alexander J, Roberts CW (2011) Selective inhibition and augmentation of alternative macrophage activation by progesterone. Immunology 134: 281-291.

62. Butts CL, Shukair SA, Duncan KM, Bowers E, Horn C, et al. (2007) Progesterone inhibits mature rat dendritic cells in a receptor-mediated fashion. Int Immuno 19: $287-296$

63. Su L, Sun Y, Ma F, Lü P, Huang H, et al. (2009) Progesterone inhibits Toll-like receptor 4-mediated innate immune response in macrophages by suppressing NF-kappaB activation and enhancing SOCS1 expression. Immunol Lett 125 151-155.

64. Krishnan L, Guilbert LJ, Russell AS, Wegmann TG, Mosmann TR, et al. (1996 Pregnancy impairs resistance of C57BL/6 mice to Leishmania major infection and causes decreased antigen-specific IFN-gamma response and increased production of T helper 2 cytokines. Journal of immunology 156: 644-652.

65. Sacks GP, Clover LM, Bainbridge DR, Redman CW, Sargent IL (2001) Flow cytometric measurement of intracellular Th1 and Th2 cytokine production by human villous and extravillous cytotrophoblast. Placenta 22: 550-559.

66. Szekeres-Bartho J, Par G, Szereday L, Smart CY, and Achatz I (1997) Progesterone and non-specific immunologic mechanisms in pregnancy. American journal of reproductive immunology 38: 176-182.

67. Arruvito L, Giulianelli S, Flores AC, Paladino N, Barboza M, et al. (2008) NK cells expressing a progesterone receptor are susceptible to progesteroneinduced apoptosis. J Immunol 180: 5746-5753.

68. Kumar P1, Sait SF (2011) Luteinizing hormone and its dilemma in ovulation induction. J Hum Reprod Sci 4: 2-7.

69. Muñoz-Cruz S, Mendoza-Rodríguez Y, Nava-Castro KE, Yepez-Mulia L, Morales-Montor J (2015) Gender-related effects of sex steroids on histamine release and FcîRRI expression in rat peritoneal mast cells. J Immunol Res 2015: 351829

70. Corrales JJ, Almeida M, Burgo R, Mories MT, Miralles JM, et al. (2006) Androgen-replacement therapy depresses the ex vivo production of inflammatory cytokines by circulating antigen- presenting cells in aging type-2 diabetic men with partial androgen deficiency. J Endocrinol 189: 595-604.

71. Page ST, Plymate SR, Bremner WJ, Matsumoto AM, Hess DL, et al. (2006) Effect of medical castration on CD4+ CD25+ T cells, CD8+ T cell IFN-gamma expression, and NK cells: a physiological role for testosterone and/or its metabolites. Am J Physiol Endocrinol Metab 290: E856-863.

72. Dalal M, Kim S, and Voskuhl RR (1997) Testosterone therapy ameliorates experimental autoimmune encephalomyelitis and induces a T helper 2 bias in the autoantigen-specific T lymphocyte response. Journal of immunology 159 : 3-6.

73. Kanda N, Tsuchida T, and Tamaki K (1996) Testosterone inhibits immunoglobulin production by human peripheral blood mononuclear cells. Clinical and experimental immunology 106: 410-415

74. Mesiano S, Jaffe RB (1997) Developmental and functional biology of the primate fetal adrenal cortex. Endocr Rev 18: 378-403.

75. Radford DJ, Wang K, McNelis JC, Taylor AE, Hechenberger G, et al. (2010) Dehydroepiandrosterone sulfate directly activates protein kinase C-beta to increase human neutrophil superoxide generation. Mol Endocrinol 24: 813-821.

76. Canning MO, Grotenhuis K, de Wit HJ, and Drexhage HA (2000) Opposing effects of dehydroepiandrosterone and dexamethasone on the generation of monocyte-derived dendritic cells. European journal of endocrinology / European Federation of Endocrine Societies 143: 687-695

77. Suzuki T, Suzuki N, Daynes RA, Engleman EG (1991) Dehydroepiandrosterone enhances IL2 production and cytotoxic effector function of human T cells. Clin Immunol Immunopathol 61: 202-211.

78. Liang J, Yao G, Yang L, Hou Y (2004) Dehydroepiandrosterone induces apoptosis of thymocyte through Fas/Fas-L pathway. Int Immunopharmacol 4 1467-1475.

79. Kiyota M, Korenaga M, Nawa Y, Kotani M (1984) Effect of androgen on the expression of the sex difference in susceptibility to infection with Strongyloides 
Citation: Aguilar-Díaz H, Nava-Castro KE, Cerbón-Cervantes MA, Meneses-Ruiz DM, Ponce-Regalado MD, et al. (2015) Endocrine Immune Interactions in the Host-Parasite Relationship: Steroid Hormones as Immune Regulators in Parasite Infections. J Steroids Horm Sci 6: 165. doi:10.4172/2157-7536.1000165

ratti in C57BL/6 mice. Aust J Exp Biol Med Sci 62 : 607-618.

80. Tiuria R, Horii Y, Tateyama S, Tsuchiya K, and Nawa Y (1994) The Indian soft-furred rat, Millardia meltada, a new host for Nippostrongylus brasiliensis, showing androgen-dependent sex difference in intestinal mucosal defence. Int J Parasitol 24: 1055-1057.

81. Hepworth MR, Hardman MJ, Grencis RK (2010) The role of sex hormones in the development of Th2 immunity in a gender-biased model of Trichuris muris infection. Eur J Immunol 40: 406-416.

82. Bancroft AJ, Artis D, Donaldson DD, Sypek JP, Grencis RK (2000) Gastrointestinal nematode expulsion in IL-4 knockout mice is IL-13 dependent. Eur J Immunol 30: 2083-2091.

83. Bancroft AJ, McKenzie AN, Grencis RK (1998) A critical role for IL-13 in resistance to intestinal nematode infection. J Immunol 160: 3453-3461.

84. Reddington JJ, Stewart GL, Kramar GW, Kramar MA (1981) The effects of hos sex and hormones on Trichinella spiralis in the mouse. J Parasitol 67: 548-555.

85. Knight PA, Brown JK, and Pemberton AD (2008) Innate immune response mechanisms in the intestinal epithelium: potential roles for mast cells and goble cells in the expulsion of adult Trichinella spiralis. Parasitology 135: 655-670.

86. Graham AL, Taylor MD, Le Goff L, Lamb TJ, Magennis M, et al. (2005) Quantitative appraisal of murine filariasis confirms host strain differences but reveals that $B A L B / c$ females are more susceptible than males to Litomosoides sigmodontis. Microbes and infection / Institut Pasteur 7: 612-618.

87. Taylor MD, LeGoff L, Harris A, Malone E, Allen JE, et al. (2005) Removal of regulatory $T$ cell activity reverses hyporesponsiveness and leads to filarial parasite clearance in vivo. J Immunol 174: 4924-4933.

88. Taylor MD, Harris A, Babayan SA, Bain O, Culshaw A, et al. (2007) CTLA-4 and CD4+ CD25+ regulatory $T$ cells inhibit protective immunity to filarial parasites in vivo. J Immunol 179: 4626-4634.

89. Hoffmann WH, Pfaff AW, Schulz-Key H, Soboslay PT (2001) Determinants for resistance and susceptibility to microfilaraemia in Litomosoides sigmodontis filariasis. Parasitology 122: 641-649.

90. Escobedo G, Camacho-Arroyo I, Hernandez-Hernandez OT, Ostoa-Saloma P Garcia-Varela M, et al. (2010) Progesterone induces scolex evagination of the human parasite Taenia solium: evolutionary implications to the host-parasite relationship. J Biomed Biotechnol 591079.

91. Escobedo G, Camacho-Arroyo I, Nava-Luna P, Olivos A, Pérez-Torres A, et al. (2011) Progesterone induces mucosal immunity in a rodent model of human taeniosis by Taenia solium. Int J Biol Sci 7: 1443-1456.

92. Morales-Montor J, Escobedo G, Rodriguez-Dorantes M, Téllez-Ascencio N Cerbón MA, et al. (2004) Differential expression of AP-1 transcription factor genes c-fos and c-jun in the helminth parasites Taenia crassiceps and Taenia solium. Parasitology 129: 233-243.

93. Ambrosio JR, Ostoa-Saloma P, Palacios-Arreola MI, Ruíz-Rosado A, SánchezOrellana PL, et al. (2014) Oestradiol and progesterone differentially alter cytoskeletal protein expression and flame cell morphology in Taenia crassiceps. International Journal for Parasitology 44: 687-696.

94. Ambrosio JR, Valverde-Islas L, Nava-Castro KE, Palacios-Arreola MI, OstoaSaloma P, et al. (2015) Androgens Exert a Cysticidal Effect upon Taenia crassiceps by Disrupting Flame Cell Morphology and Function. PLoS One 10: e0127928.

95. Morales-Montor J, Mohamed F, Ghaleb AM, Baig S, Hallal-Calleros C, et al. (2001) In vitro effects of hypothalamic-pituitary-adrenal axis (HPA) hormones on Schistosoma mansoni. J Parasitol 87: 1132-1139.

96. Eloi-Santos S, Olsen NJ, Correa-Oliveira R, Colley DG (1992) Schistosoma mansoni: mortality, pathophysiology, and susceptibility differences in male and female mice. Exp Parasitol 75: 168-175.

97. Morales-Montor J, Mohamed F, Damian RT (2004) Schistosoma mansoni: the effect of adrenalectomy on the murine model. Microbes Infect 6: 475-480.

98. Degu G, Mengistu G, Jones J (2002) Some factors affecting prevalence of and immune responses to Schistosoma mansoni in schoolchildren in Gorgora, northwest Ethiopia. Ethiop Med J 40: 345-352.

99. Remoué F, Mani JC, Pugnière M, Schacht AM, Capron A, et al. (2002) Functional specific binding of testosterone to Schistosoma haematobium 28-kilodalton glutathione S-transferase. Infect Immun 70: 601-605.
100.Dissanayake S (2000) Upregulation of a raf kinase and a DP-1 family transcription factor in epidermal growth factor (EGF) stimulated filarial parasites. Int J Parasitol 30: 1089-1097.

101. Gomez Y, Valdez RA, Larralde C, and Romano MC (2000) Sex steroids and parasitism: Taenia crassiceps cisticercus metabolizes exogenous androstenedione to testosterone in vitro. The Journal of steroid biochemistry and molecular biology 74: 143-147.

102. Walker W, Roberts CW, Ferguson DJ, Jebbari H, Alexander J (1997) Innate immunity to Toxoplasma gondii is influenced by gender and is associated with differences in interleukin-12 and gamma interferon production. Infect Immun 65: 1119-1121.

103. Roberts CW, Cruickshank SM, Alexander J (1995) Sex-determined resistance to Toxoplasma gondii is associated with temporal differences in cytokine production. Infect Immun 63: 2549-2555.

104. Liesenfeld O, Nguyen TA, Pharke C, Suzuki Y (2001) Importance of gender and sex hormones in regulation of susceptibility of the small intestine to perora infection with Toxoplasma gondii tissue cysts. J Parasitol 87: 1491-1493.

105.Pung OJ, Luster MI (1986) Toxoplasma gondii: decreased resistance to infection in mice due to estrogen. Exp Parasitol 61: 48-56.

106. Kaňková S, Kodym P, Flegr J (2011) Direct evidence of Toxoplasma-induced changes in serum testosterone in mice. Exp Parasitol 128: 181-183.

107. Arnott MA, Cassella JP, Aitken PP, Hay J (1990) Social interactions of mice with congenital Toxoplasma infection. Ann Trop Med Parasitol 84: 149-156.

108. Webster JP, Brunton CF, MacDonald DW (1994) Effect of Toxoplasma gondi upon neophobic behaviour in wild brown rats, Rattus norvegicus. Parasitology $109: 37-43$

109. Yap GS, Shaw MH, Ling Y, Sher A (2006) Genetic analysis of host resistance to intracellular pathogens: lessons from studies of Toxoplasma gondii infection. Microbes Infect 8: 1174-1178.

110. Debierre-Grockiego F, Campos MA, Azzouz N, Schmidt J, Bieker U, et al (2007) Activation of TLR2 and TLR4 by glycosylphosphatidylinositols derived from Toxoplasma gondii. J Immunol 179: 1129-1137.

111. Aosai F, Rodriguez Pena MS, Mun HS, Fang H, Mitsunaga T, et al. (2006) Toxoplasma gondii-derived heat shock protein 70 stimulates maturation of murine bone marrow-derived dendritic cells via Toll-like receptor 4 . Cell Stress Chaperones 11: 13-22.

112. Mun HS, Aosai F, Norose K, Piao LX, Fang H, et al. (2005) Toll-like receptor 4 mediates tolerance in macrophages stimulated with Toxoplasma gondiiderived heat shock protein 70. Infect Immun 73: 4634-4642.

113. Lauw FN, Caffrey DR, Golenbock DT (2005) Of mice and man: TLR11 (finally) finds profilin. Trends Immunol 26: 509-511.

114. Aliberti J, Valenzuela JG, Carruthers VB, Hieny S, Andersen J, et al. (2003) Molecular mimicry of a CCR5 binding-domain in the microbial activation of dendritic cells. Nat Immunol 4: 485-490.

115. Parker SJ, Roberts CW, and Alexander J (1991) CD8+ T cells are the majo lymphocyte subpopulation involved in the protective immune response to Toxoplasma gondii in mice. Clinical and experimental immunology 84: 207212.

116. Combe CL, Curiel TJ, Moretto MM, Khan IA (2005) NK cells help to induce CD8(+)-T-cell immunity against Toxoplasma gondii in the absence of CD4(+) T cells. Infect Immun 73: 4913-4921.

117. Venugopalan PP, Shenoy DU, Kamath A, Rajeev A (1997) Distribution of malarial parasites: effect of gender of construction workers. Indian J Med Sci 51: 89-92.

118. Landgraf B, Kollaritsch H, Wiedermann G, Wernsdorfer WH (1994) Parasite density of Plasmodium falciparum malaria in Ghanaian schoolchildren: evidence for influence of sex hormones? Trans R Soc Trop Med Hyg 88: 7374.

119. Wildling E, Winkler S, Kremsner PG, Brandts C, Jenne L, et al. (1995) Malaria epidemiology in the province of Moyen Ogoov, Gabon. Trop Med Parasito 46: 77-82.

120. Kochar DK, Thanvi I, Joshi A, Shubhakaran, Agarwal N, et al. (1999) Mortality trends in falciparum malaria--effect of gender difference and pregnancy. J Assoc Physicians India 47: 774-778.

121. Maswoswe SM, Peters W, Warhurst DC (1985) Corticosteroid stimulation of 
Citation: Aguilar-Díaz H, Nava-Castro KE, Cerbón-Cervantes MA, Meneses-Ruiz DM, Ponce-Regalado MD, et al. (2015) Endocrine Immune Interactions in the Host-Parasite Relationship: Steroid Hormones as Immune Regulators in Parasite Infections. J Steroids Horm Sci 6: 165. doi:10.4172/2157-7536.1000165

the growth of Plasmodium falciparum gametocytes in vitro. Ann Trop Med Parasitol 79: 607-616.

122. Lingnau A, Margos G, Maier WA, Seitz HM (1993) The effects of hormones on the gametocytogenesis of Plasmodium falciparum in vitro. Appl Parasitol 34: 153-160.

123. Bayoumi NK, Elhassan EM, Elbashir MI, Adam I (2009) Cortisol, prolactin, cytokines and the susceptibility of pregnant Sudanese women to Plasmodium falciparum malaria. Ann Trop Med Parasitol 103: 111-117.

124. Cernetich A, Garver LS, Jedlicka AE, Klein PW, Kumar N, et al. (2006) Involvement of gonadal steroids and gamma interferon in sex differences in response to blood-stage malaria infection. Infect Immun 74: 3190-3203.

125. Benten WP, Wunderlich F, Mossmann H (1992) Testosterone-induced suppression of self-healing Plasmodium chabaudi malaria: an effect not mediated by androgen receptors? J Endocrinol 135: 407-413.

126. Benten WP, Wunderlich F, Mossmann H (1992) Plasmodium chabaudi: estradiol suppresses acquiring, but not once-acquired immunity. Exp Parasito 75: $240-247$.

127.Benten WP, Wunderlich F, Herrmann R, and Kuhn-Velten WN (1993) Testosterone-induced compared with oestradiol-induced immunosuppression against Plasmodium chabaudi malaria. J Endocrinol 139: 487-494.

128. Wunderlich F, Benten WP, Lieberherr M, Guo Z, Stamm O, et al. (2002) Testosterone signaling in T cells and macrophages. Steroids 67: $535-538$.

129. Mossmann H, Benten WP, Galanos C, Freudenberg M, Kühn-Velten WN, et al. (1997) Dietary testosterone suppresses protective responsiveness to Plasmodium chabaudi malaria. Life Sci 60: 839-848.

130. Benten WP, Bettenhaeuser U, Wunderlich F, Van Vliet E, Mossmann H (1991) Testosterone-induced abrogation of self-healing of Plasmodium chabaudi malaria in B10 mice: mediation by spleen cells. Infect Immun 59: 4486-4490.

131.Legorreta-Herrera M, Mosqueda-Romo NA, Nava-Castro KE, MoralesRodríguez AL, Buendía-González FO, et al. (2015) Sex hormones modulate the immune response to Plasmodium berghei ANKA in CBA/Ca mice. Parasitol Res 114: 2659-2669.

132. Mosqueda-Romo NA, Rodríguez-Morales AL, Buendía-González FO, AguilarSánchez M, Morales-Montor J, et al. (2014) Gonadal steroids negatively modulate oxidative stress in $\mathrm{CBA} / \mathrm{Ca}$ female mice infected with $\mathrm{P}$. berghei ANKA. Biomed Res Int 2014: 805495.

133. Aley SB, Zimmerman M, Hetsko M, Selsted ME, Gillin FD (1994) Killing of Giardia lamblia by cryptdins and cationic neutrophil peptides. Infect Immun 62: 5397-5403.

134. Carrero JC, Cervantes C, Moreno-Mendoza N, Saavedra E, Morales-Montor $J$, et al. (2006) Dehydroepiandrosterone decreases while cortisol increases in vitro growth and viability of Entamoeba histolytica. Microbes and infection / Institut Pasteur 8: 323-331.

135. Seydel KB, Smith SJ, Stanley SL Jr (2000) Innate immunity to amebic liver abscess is dependent on gamma interferon and nitric oxide in a murine model of disease. Infect Immun 68: 400-402.

136.Li E, Zhou P, Petrin Z, Singer SM (2004) Mast cell-dependent control of Giardia lamblia infections in mice. Infect Immun 72: 6642-6649.

137. Daniels CW, Belosevic M (1995) Comparison of the course of infection with Giardia muris in male and female mice. Int J Parasitol 25: 131-135.

138. Daniels CW, Belosevic M (1995) Disaccharidase activity in male and female C57BL/6 mice infected with Giardia muris. Parasitol Res 81: 143-147.

139. Daniels CW, Belosevic M (1994) Serum antibody responses by male and female C57BI/6 mice infected with Giardia muris. Clin Exp Immunol 97: 424429.

140. Acuna-Soto R, Maguire JH, Wirth DF (2000) Gender distribution in asymptomatic and invasive amebiasis. Am J Gastroenterol 95: 1277-1283.

141. Lotter H, Jacobs T, Gaworski I, Tannich E (2006) Sexual dimorphism in the control of amebic liver abscess in a mouse model of disease. Infect Immun 74: 118-124.

142. Chapman WL Jr, Hanson WL, Waits VB (1975) The influence of gonadectomy of host on parasitemia and mortality of mice infected with Trypanosoma cruzi. J Parasitol 61: 213-216.
143. de Souza EM, Rivera MT, Araújo-Jorge TC, de Castro SL (2001) Modulation induced by estradiol in the acute phase of Trypanosoma cruzi infection in mice. Parasitol Res 87: 513-520.

144. dos Santos CD, Toldo MP, do Prado Júnior JC (2005) Trypanosoma cruzi: the effects of dehydroepiandrosterone (DHEA) treatment during experimental infection. Acta Trop 95: 109-115.

145. D'Ambrosio Fernandes R, Caetano LC, dos Santos CD, Abrahao AA, Pinto AC et al. (2008) Alterations triggered by steroid gonadal hormones in triglycerides and the cellular immune response of Calomys callosus infected with the $Y$ strain of Trypanosoma cruzi. Vet Parasitol 152: 21-27.

146. Basquiera AL, Sembaj A, Aguerri AM, Omelianiuk M, Guzman S, et al. (2003) Risk progression to chronic Chagas cardiomyopathy: influence of male sex and of parasitaemia detected by polymerase chain reaction. Heart 89: 11861190 .

147. Brabin L, Brabin BJ (1992) Parasitic infections in women and their consequences. Adv Parasitol 31: 1-81.

148. Ghansah TJ, Ager EC, Freeman-Junior P, Villalta F, and Lima MF (2002) Epidermal growth factor binds to a receptor on Trypanosoma cruzi amastigotes inducing signal transduction events and cell proliferation. J Eukaryot Microbio 49: 383-390.

149. Kuehn CC, Oliveira LG, Santos CD, Augusto MB, Toldo MP, et al. (2011) prior and concomitant dehydroepiandrosterone treatment affects immunologic response of cultured macrophages infected with Trypanosoma cruzi in vitro? Vet Parasitol 177: 242-246.

150.Santos CD, Toldo MP, Santello FH, Filipin Mdel V, Brazão V, et al. (2008) Dehydroepiandrosterone increases resistance to experimental infection by Trypanosoma cruzi. Vet Parasitol 153: 238-243.

151. Bisser S, Ouwe-Missi-Oukem-Boyer ON, Toure FS, Taoufiq Z, Bouteille B, et al. (2006) Harbouring in the brain: A focus on immune evasion mechanisms and their deleterious effects in malaria and human African trypanosomiasis. Int J Parasitol 36: 529-540.

152. Barry JD, McCulloch R (2001) Antigenic variation in trypanosomes: enhanced phenotypic variation in a eukaryotic parasite. Adv Parasitol 49: 1-70.

153. Vanhamme L, Pays E, McCulloch R, Barry JD (2001) An update on antigenic variation in African trypanosomes. Trends Parasitol 17: 338-343.

154. Greenblatt HC, Rosenstreich DL (1984) Trypanosoma rhodesiense infection in mice: sex dependence of resistance. Infect Immun 43: 337-340.

155. Pépin J, Milord F, Khonde A, Niyonsenga T, Loko L, et al. (1994) Gambiense trypanosomiasis: frequency of, and risk factors for, failure of melarsoprol therapy. Trans R Soc Trop Med Hyg 88: 447-452.

156. Hublart M, Tetaert D, Croix D, Boutignon F, Degand P, et al. (1990) Gonadotropic dysfunction produced by Trypanosoma brucei brucei in the rat Acta Trop 47: 177-184.

157. Soudan B, Tetaert D, Hublart M, Racadot A, Croix D, et al. (1993) Experimental "chronic" African trypanosomiasis: endocrine dysfunctions generated by parasitic components released during the tryptanolytic phase in rats. Exp Clin Endocrinol 101: 166-172.

158. Soudan B, Tetaert D, Racadot A, Degand P, and Boersma A (1992) Decrease of testosterone level during an experimental African trypanosomiasis: involvement of a testicular LH receptor desensitization. Acta Endocrino (Copenh) 127: 86-92.

159. Boersma A, Noireau F, Hublart M, Boutignon F, Lemesre JL, et al. (1989) Gonadotropic axis and Trypanosoma brucei gambiense infection. Ann Soc Belg Med Trop 69: 127-135

160. Aguilar-Delfin I, Homer MJ, Wettstein PJ, Persing DH (2001) Innate resistance to Babesia infection is influenced by genetic background and gender. Infect Immun 69: 7955-7958.

161. Hughes VL, Randolph SE (2001) Testosterone increases the transmission potential of tick-borne parasites. Parasitology 123: 365-371.

162. Hughes VL, Randolph SE (2001) Testosterone depresses innate and acquired resistance to ticks in natural rodent hosts: a force for aggregated distributions of parasites. J Parasitol 87: 49-54.

163. Barnard CJ, Behnke JM, and Sewell J (1994) Social behaviour and susceptibility to infection in house mice (Mus musculus): effects of group size, aggressive behaviour and status-related hormonal responses prior to infection 
Citation: Aguilar-Díaz H, Nava-Castro KE, Cerbón-Cervantes MA, Meneses-Ruiz DM, Ponce-Regalado MD, et al. (2015) Endocrine Immune Interactions in the Host-Parasite Relationship: Steroid Hormones as Immune Regulators in Parasite Infections. J Steroids Horm Sci 6: 165. doi:10.4172/2157-7536.1000165

on resistance to Babesia microti. Parasitology 108: 487-496.

164. Wood PR, Clark IA (1982) Apparent irrelevance of NK cells to resolution of infections with Babesia microti and Plasmodium vinckei petteri in mice. Parasite Immunol 4: 319-327.

165. Ford LC, Hammill HA, DeLange RJ, Bruckner DA, Suzuki-Chavez F, et al. (1987) Determination of estrogen and androgen receptors in Trichomonas vaginalis and the effects of antihormones. Am J Obstet Gynecol 156: 11191121

166. Cappuccinelli P, Lattes C, Cagliani I, Negro Ponzi A (1974) Features of intravaginal Trichomonas vaginalis infection in the mouse and the effect of oestrogen treatment and immunodepression. G Batteriol Virol Immunol 67: $31-40$.

167. Van Andel RA, Kendall LV, Franklin CL, Riley LK, Besch-Williford CL, et al. (1996) Sustained estrogenization is insufficient to support long-term experimentally induced genital Trichomonas vaginalis infection in BALB/c mice. Lab Anim Sci 46: 689-690.

168. Azuma $\mathrm{T}$ (1968) A study on the parasiting condition of trichomonas vaginalis with special reference to the relationship between estrogen and the growth of trichomonas vaginalis. J Jpn Obstet Gynecol Soc 15: 168-172.

169. Brown MT (1972) Trichomoniasis. Practitioner 209: 639-644.

170.Landolfo S, Martinotti MG, Martinetto P, Forni G, Rabagliati AM (1981) Trichomonas vaginalis: dependence of resistance among different mouse strains upon the non-H-2 gene haplotype, sex, and age of recipient hosts. Exp Parasitol 52: 312-318.

171. Sugarman B, Mummaw N (1988) The effect of hormones on Trichomonas vaginalis. J Gen Microbiol 134: 1623-1628.

172. Garber GE, Lemchuk-Favel LT, Rousseau G (1991) Effect of beta-estradio on production of the cell-detaching factor of Trichomonas vaginalis. J Clin Microbiol 29: 1847-1849.
173. Lynch NR, Yarzábal L, Verde O, Avila JL, Monzon H, et al. (1982) Delayed-type hypersensitivity and immunoglobulin $\mathrm{E}$ in American cutaneous leishmaniasis. Infect Immun 38: 877-881.

174. Mock BA, Nacy CA (1988) Hormonal modulation of sex differences in resistance to Leishmania major systemic infections. Infect Immun 56: 33163319

175. Lezama-Dávila CM, Isaac-Márquez AP, Barbi J, Cummings HE, Lu B, et al (2008) Role of phosphatidylinositol-3-kinase-gamma (PI3Kgamma)-mediated pathway in 17beta-estradiol-induced killing of L. mexicana in macrophages from C57BL/6 mice. Immunol Cell Biol 86: 539-543.

176. Liu L, Wang L, Zhao Y, Wang Y, Wang Z, et al. (2006) Testosterone attenuates p38 MAPK pathway during Leishmania donovani infection of macrophages. Parasitol Res 99: 189-193.

177. Nandan D, and Reiner NE (1995) Attenuation of gamma interferon-induced tyrosine phosphorylation in mononuclear phagocytes infected with Leishmania donovani: selective inhibition of signaling through Janus kinases and Stat1. Infection and immunity 63: 4495-4500.

178. Bhardwaj N, Rosas LE, Lafuse WP, and Satoskar AR (2005) Leishmania inhibits STAT1-mediated IFN-gamma signaling in macrophages: increased tyrosine phosphorylation of dominant negative STAT1beta by Leishmania mexicana. Int J Parasitol 35: 75-82.

179. Bhardwaj S, Srivastava N, Sudan R, Saha B (2010) Leishmania interferes with host cell signaling to devise a survival strategy. J Biomed Biotechnol 2010: 109189.

180. Hernandez-Bello R, Escobedo G, Guzman C, Ibarra-Coronado EG, LopezGriego L, et al. (2010) Immunoendocrine host-parasite interactions during helminth infections: from the basic knowledge to its possible therapeutic applications. Parasite immunology 32: 633-643.

181. Mao G, Wang J, Kang Y, Tai P, Wen J, et al. (2010) Progesterone increases systemic and local uterine proportions of CD4+CD25+ Treg cells during midterm pregnancy in mice. Endocrinology 151: 5477-5488. 